https://dx.doi.org/10.4314/ijs.v23i2.10

Ife Journal of Science vol. 23, no. 2 (2021)

\title{
ORAL ADMINISTRATION OF Weissella AND Pediococcus sp ALLEVIATES FORMALIN INDUCED INFLAMMATION IN RATS BY CYTOKINE MODULATION
}

\author{
*Oladejo, B. O. and Oluwasola, H. M. \\ Department of Microbiology, Federal University of Technology, P.M.B. 704, Akure, Nigeria. \\ *Corresponding author's email: booladejo@futa.edu.ng; Tel: +2349042422526
}

(Received: 24 ${ }^{\text {th }}$ March, 2021; Accepted: $20^{\text {th }}$ July, 2021)

ABSTRACT

\begin{abstract}
This study was designed to study the cytokine modulatory activity of three lactic acid bacteria (LAB) strains, Weisella cibaria II-1-59, Weisella confusa JMC 1093, and Pediococcus pentosaceus DSM20336 isolated from a Nigerian locally fermented food condiment; "iru" using paw oedema acute inflammatory model induced with 1\% formalin in Wistar rats. Rats were distributed into six groups (A-F). Rats in Groups A were neither administered formalin nor treated with LAB, while Group B received formalin injection only. Rats in Groups C, D, and E were administered formalin and were treated orally with $2 \times 10^{7} \mathrm{CFU} / \mathrm{ml}$ of Weisella cibaria II-1-59, Weisella confusa JMC 1093, and Pediococcus pentosaceus DSM20336 respectively, while Group F received diclofenac sodium treatment following administration of formalin. The dose of LAB strain used for the oral treatment was $2 \times 10^{7}$ $\mathrm{CFU} / \mathrm{ml}$ for all the groups while the dose of diclofenac sodium used was $150 \mathrm{mg} / \mathrm{kg}$ body weight of the rats. Paw thickness (mm) was checked at $\mathrm{t}=0,1,4,8,24,72,168$ and $336 \mathrm{~h}$. Cytokine assay for C-reactive protein (CRP), Interleukin (IL-10) and Transforming growth factor (TGF- $\beta$ ) was performed on serum samples of the rats using Enzyme-linked immunosorbent assay (ELISA). Oral administration of W. cibaria II-1-59 showed the best significant decrease in the paw thickness of the rats, which was followed by P. pentosaceus DSM20336 and $W$. confusa JMC 1093 respectively, and was shown to be statistically significant at $\mathrm{P}<0.05$. There was also a significant decrease (below standard $2000 \mathrm{pg} / \mathrm{ml}$ ) in the secretion of pro-inflammatory biomarker (CRP) in all LAB treated groups at 1 hour, while there was an increase in the serum levels of anti-inflammatory cytokines IL-10 and TGF$\beta$ in Groups C-E rats which was maximally increased in W. confusa JMC 1093 treated rats. This study suggests that W. cibaria II-1-59, W. confusa JMC 1093 and P. pentosaceus DSM20336 possess anti-inflammatory potentials.
\end{abstract}

Keywords: Inflammation, Cytokines, Weisella, Formalin, Oedema, Pediococcus

\section{INTRODUCTION}

The immune system of the body recognizes and removes harmful stimuli in a bid to initiate the healing process or recovery from variety of factors such as pathogens, damaged cells, stress, and irritation which triggers a series of inflammatory responses (Michels et al., 2019). Inflammation can be induced as a result of trauma, microbial invasion, or noxious compounds and can later result to tissue damage. It starts rapidly, becomes severe in a short time and symptoms may last for a few days (Jain et al., 2015).

Cytokines are important regulators of inflammatory responses in the body. They are pleiotropic proteins or small glycoproteins produced by a number of cell types, such as leukocytes which regulate immunity, inflammation and hematopoiesis (Gulati et al., 2016). Cytokines are secreted proteins that have a specific effect on the interactions and communications between cells. They include interleukins, chemokines, interferons, and tumor necrosis factors, which have a multitude of pleiotropic effects in various organs (Monastero and Pentyala, 2017). Cytokines involved in inflammatory responses are basically of two types: pro-inflammatory and anti-inflammatory cytokines. Pro-inflammatory cytokines act in concert to generate inflammation in host defense and disease, but anti-inflammatory cytokines attenuate inflammation and induce repair (Gulati et al., 2016).

There are various components to an inflammatory reaction injury; such as oedema formation, leukocyte infiltration and granuloma. Oedema formation in the paw is the result of a synergism between various inflammatory mediators that increases vascular permeability and blood flow (John and Shobana, 2012). Although some acceptable results have been achieved with the use of conventional drugs like non-steroidal antiinflammatory drugs (NSAIDs), corticosteroids and herbal supplements for the treatment of inflammation, yet a life-threatening condition of chronic diseases that presents a major threat to the health and longevity of individuals still exists 
(Barcelos et al., 2019). Hence, there is a need for an alternative source of treatment.

A fermented locust bean ('Iru') is a very good source of a number of microbial strains, especially from the genera of Lactobacillus, Leuconostoc, Pediococcus and Bacillus (Afolabi et al., 2016). Lactic acid bacteria (LAB) are also known as probiotics and can act as immune-modulators (Pessione, 2012). These organisms confer health benefit on the host when administered in sufficient amount. Formalin is a strong chemical used to induce acute inflammation. Formalin induced paw oedema in rat is one of the most suitable tests to screen for inflammatory responses.

Therefore, this study aims to evaluate the antiinflammatory properties and cytokine mediated immune-regulating activities of lactic acid bacteria isolated from indigenous fermented locust beans ('Iru') using Wistar rats induced with formalin.

\section{MATERIALS AND METHODS Collection of Samples}

Fermented locust bean ('Iru') was purchased from Oba market, Akure, Ondo State, southwest, Nigeria. The samples were put in a sterile polythene bag and transported immediately to the Department of Microbiology Laboratory, Federal University of Technology, Akure for bacteriological analysis.

\section{Isolation and Identification of Bacteria}

The types of bacteria present in the fermented locust bean ('Iru') were isolated and identified using standard microbiological methods as described by Bin Masalam et al., (2018). Molecular identification of the isolated LAB was carried out by harvesting cell pellets from $2 \mathrm{ml}$ of overnight cultures (about $2 \times 10^{\circ}$ bacterial cells) of LAB grown in De Mann Rogosa and Sharpe Agar (MRS) broth and DNA extraction was done using a JenaBioscience DNA purification kit following the manufacturer's instructions. Polymerase chain reaction (PCR) was carried out to amplify the 16 srRNA gene of the bacteria using the primer pair 27F-5'-AGAGTTTGATCCTGGCTCAG3', and 1492R 5'GGTTACCTTGTTACGACTT3'. The amplification product was separated on a $1.5 \%$ agarose gel and electrophoresis was carried out at $80 \mathrm{~V}$ for 1 hour 30 minutes. After electrophoresis, DNA bands were visualized by ethidium bromide staining. A $100 \mathrm{bp}$ DNA ladder (Solis Biodyne) was used as DNA molecular weight marker. For the sequencing, PCR products were purified with Exo sap and then subjected to DNA Sanger sequencing after which the resulting data was analyzed by ABI Sequencing Analysis software (version 5.2). They were then BLASTsearched to detect similar sequences in the NCBI database.

\section{Drugs and Reagents}

Formalin, diclofenac sodium (Impulse Pharma Pvt. Ltd, Boisar, India.), and cytokines ELISA assay kits; CR-P, IL-10 and TGF-beta (MELSIN medical co. Limited, Jilin province, China) were purchased for the assay.

\section{Evaluation of Anti-inflammatory Activity}

Healthy male Wistar rats with an average weight of $150 \mathrm{~g}$ were used for this present study. The rats were housed in stainless steel cages. They were fed with standard commercial rat feed and water and allowed to acclimatize for one week before the experimental session. For the anti-inflammatory assay, inflammation was first induced by subplantar injection of $0.1 \mathrm{ml}$ of $1 \%$ freshly prepared formalin into the right hind paws of all the rats except the rats in general control group (Group A). After inflammation had been induced, which was observed physically by the swelling and redness of the paw as seen in paw volume measurements, rats were divided into 5 groups (Groups B - F) of 3 rats each. Rats in Group B were administered formalin only without any treatment (negative control); rats in Group C, D, and $\mathrm{E}$ were administered formalin and were treated orally with $2 \times 10^{7} \mathrm{CFU} / \mathrm{ml}$ of $W$. cibaria II-1-59, W. confusa JMC 1093, and P. pentosaceus DSM20336 respectively while rats in Group F (positive control) were administered formalin and treated with diclofenac sodium $(150 \mathrm{mg} / \mathrm{Kg}$ body weight) after the development of paw oedema in the rats. Changes in rat paw thickness was measured at $20 \mathrm{~min}$ before injection at $0 \mathrm{hr}$ and after LAB treatment following the sub-plantar injection of formalin at different time intervals (1, $4,8,24,72,168$ and $336 \mathrm{~h}$ ) with a digital vernier caliper measured in millimeters ( $\mathrm{mm}$ ) (Amdekar et al., 2012). All the experimental procedures were 
carried out following the guidelines of the Institutional Animals Ethics Committee of the Federal University of Technology Akure, Nigeria.

\section{Blood Sample Collection}

At different intervals earlier mentioned, the rats were bled through cardio puncture according to the guidelines of Committee for the Purpose of Control and Supervision of Experiment on Animals (CPCSEA). Blood samples collected were subjected to cytokine ELISA assays. Blood samples for the cytokine assay were allowed to coagulate for 60 minutes at room temperature and then centrifuged at $1500 \mathrm{~g}$ for 15 minutes and crude serum was kept in new cryovial tubes. The harvested serum was stored at $-20{ }^{\circ} \mathrm{C}$ until use (Amdekar etal., 2012).

\section{Cytokine Assay}

C-reactive protein (CRP) levels (Proinflammatory biomarker) in nanogram per millilitre $(\mathrm{ng} / \mathrm{ml})$ for acute phase proteins produced in the liver, IL-10 and TGF- $\beta$ (antiinflammatory cytokines) in picogram per millilitre $(\mathrm{pg} / \mathrm{ml})$ were estimated with an ELISA analyzer reader (Labtech Auto Elisa P, Mumbai, India). Serum samples were used to perform the assay according to the method of Valentini et al. (2015).

\section{Statistical Analysis}

Data were expressed as the mean \pm standard error of mean (SEM) calculated over independent time frame of experiments performed in triplicate. One-way analysis of variance (ANOVA) was applied followed by post hoc test. Bonferroni's Multiple Comparison Test for difference between treatments groups compared with control (Group B) was done using GraphPad Prism version 5.0.

\section{RESULTS}

\section{A. Isolation and Identification of Lactobacillus sp}

Table 1 shows the three (3) LAB strains that were isolated from 'Iru' sample, The BLAST search of Genbank for all the LAB isolates provided the percentage similarity between the bacteria tested and those detected in Genbank. The 16srRNA sequence analysis identified the isolates to be Weisella cibaria II-1-59, Weisella confusa JMC 1093, and Pediococcuspentosaceus DSM20336.

Table 1: Molecular Identities of Lactic acid bacteria (LAB) Isolated from Fermented Locust Bean ('Iru')

\begin{tabular}{lllcll}
\hline Isolate code & Biochemical identity & Molecular identity & $\%$ similarity & Strain no. & Accession no. \\
\hline HBL1 & Lactobacillus sp. & Weisella cibaria & $97.27 \%$ & II-1-59 & NR_036924.1 \\
HBL2 & Lactobacillus sp. & Weisella confusa & $96.77 \%$ & JMC 1093 & NR_040816.1 \\
HBL3 & Pediococcus sp. & Pediococcus pentosaceus & $95.84 \%$ & DSM20336 & NR_042058.1 \\
\hline
\end{tabular}

B. Effects of Weisella sp and Pediococcus in Formalin Induced Inflammation in Rat Paw Tissues

Figure 1 shows changes in paw thickness $(\mathrm{mm})$ of rats before and during LAB treatments. At 1 hour post sub-plantar injection of $0.1 \mathrm{ml}$ of $1 \%$ solution of formalin, the highest paw thickness was recorded in formalin inflamed Wistar rats. The paw thickness of rats in group A (Normal control) at 0 hour was $7.43 \pm 0.00 \mathrm{~mm}$ which remained constant throughout the period of the experiment. Group B rats showed the most increase in the paw thickness after the first hour of injection, which was significant at $\mathrm{p}<0.05$. Significant decrease was only observed in this group after $72 \mathrm{hrs}$, which was gradual till the end of 336 hrs. In Group C, D and E (LAB treated Groups), significant decrease in paw volume was observed after $4 \mathrm{hrs}$ of treatment till the end of the experiment. Group F (Diclofenac treated group) showed the least increase in paw volume after the first hour when compared with other treatment groups. The values were tested for statistical significance at $p<0.05$ and the effect of treatment means was compared. 


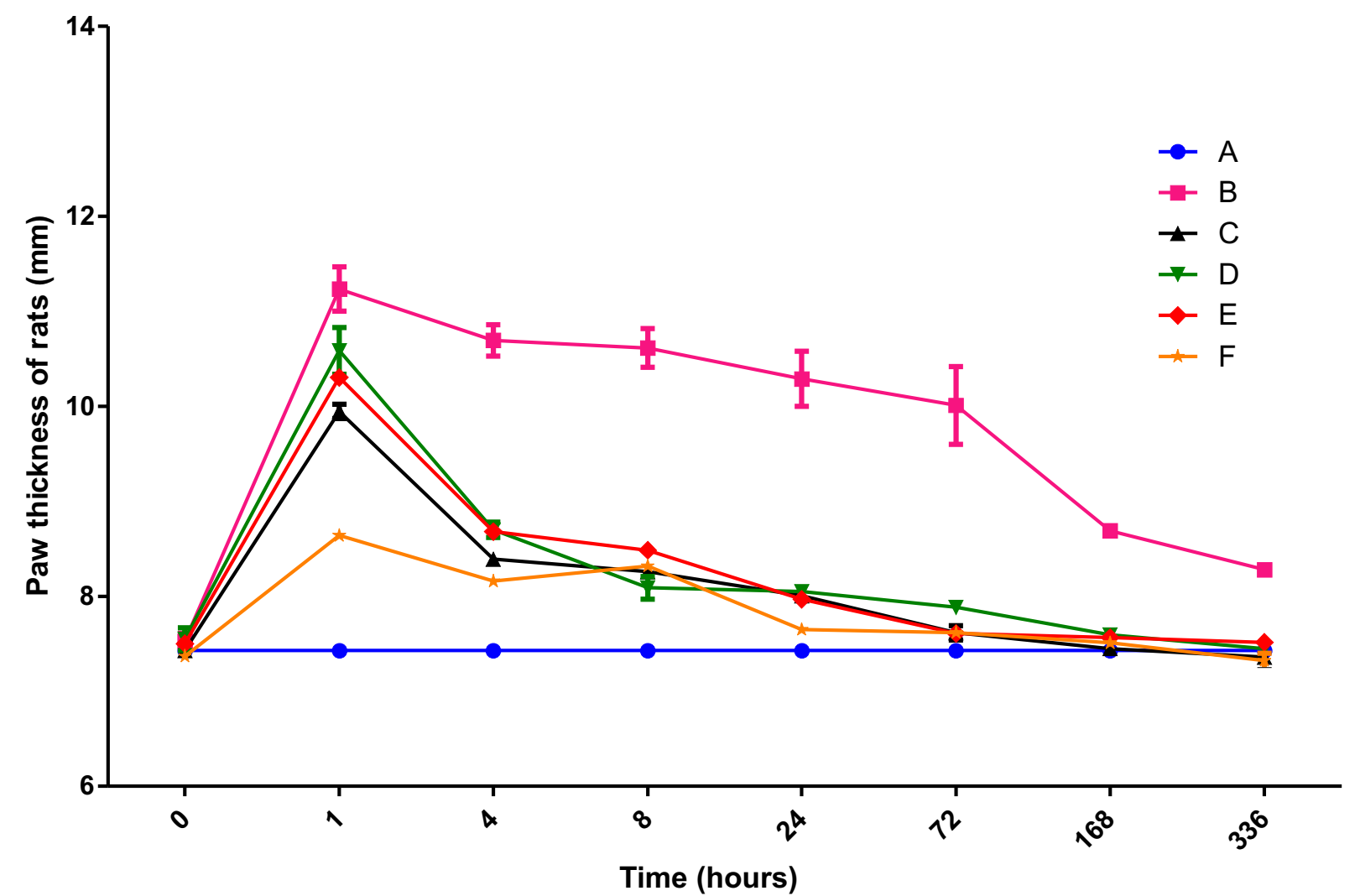

Figure 1: Change in Paw Thickness $(\mathrm{mm})$ of Rats before and during LAB Treatment at $\mathrm{t}=0,1$, $4,8,24,72,168$, and $336 \mathrm{hrs}$

$\mathrm{n}=3$ (significant at $\mathrm{P}<0.05$ ). Data are expressed as mean \pm standard error of three rats per group. Group A: neither induced nor treated; Group B: Formalin only (negative control); Group C: treated with W. cibaria II-1-59; Group D: treated with W. confusa JMC 1093; Group E: treated with P. pentosaceus DSM20336; Group F: treatment with diclofenac sodium (positive control). Values were found statistically significant at $\mathrm{P}<0.05$.

\section{Pro-inflammatory Biomarker (CRP)}

Figure 2 reveals the secretion of CRP in all the groups of the rats within the first hour of the experiment which was induced by the injection of formalin into the right hind paw of the rats. In Group A, serum CRP levels was shown to be $300.00 \pm 0.00 \mathrm{ng} / \mathrm{ml}$ which remained constant throughout the period of the experiment. The highest CRP concentration was observed in
Group F rats after 8 hours $(3943.00 \pm 0.00 \mathrm{ng} / \mathrm{ml})$ and followed by Group $\mathrm{E}$ rats at the first hour (3261.00 $\pm 0.00 \mathrm{ng} / \mathrm{ml}$ ). Additionally, the LAB treated groups showed significant reduction in the CRP levels after $24 \mathrm{hrs}$ till the end of $336 \mathrm{hrs}$. Also, significant reduction in the CRP levels was observed in Group F after 36 hours compared with other treatment groups 


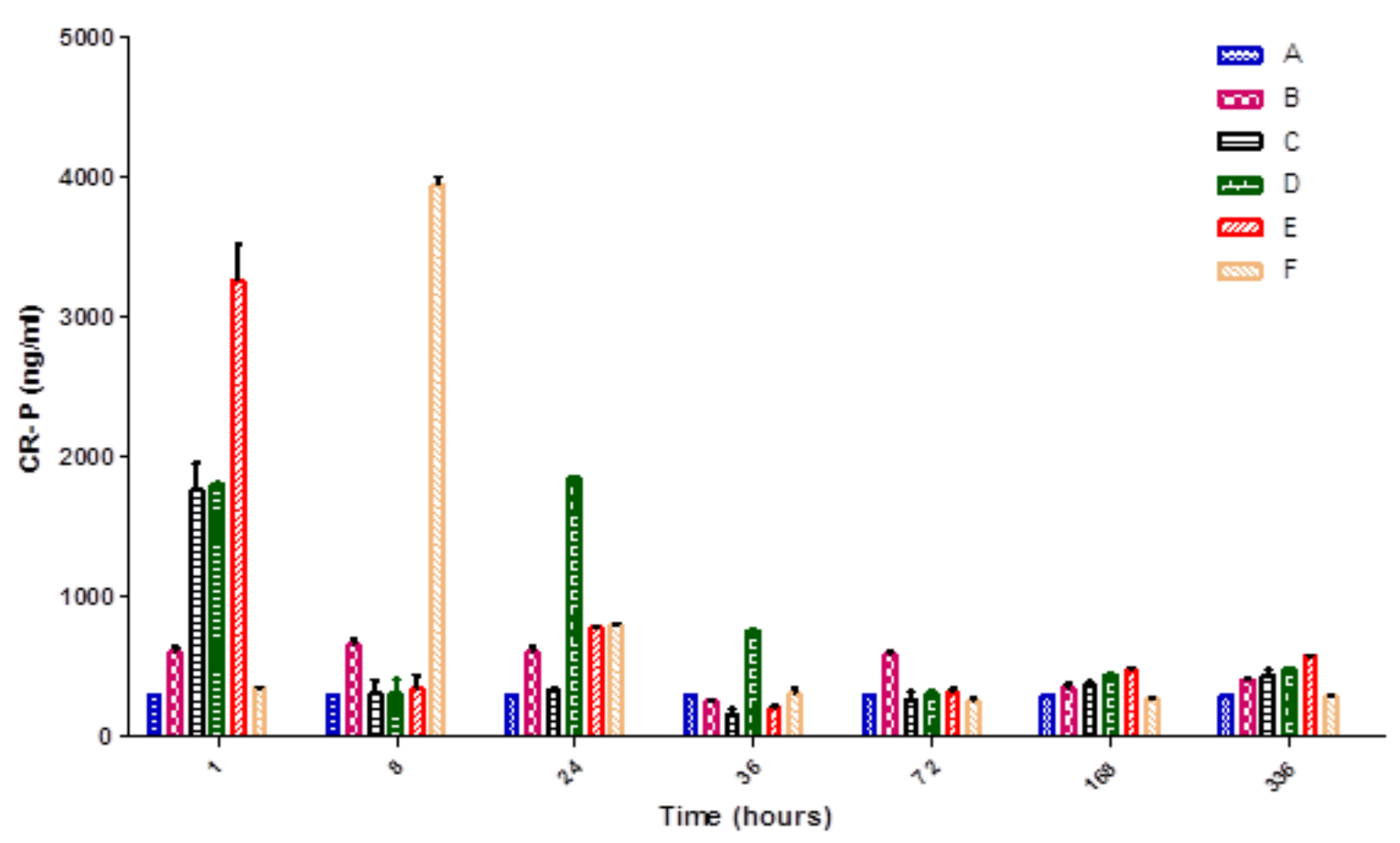

Figure 2: Production of CRP (ng/ml) at $\mathrm{t}=1,8,24,36,72,168$ and $336 \mathrm{hrs}$

$\mathrm{n}=3$ (significant at $\mathrm{P}<0.05$ ). Data are expressed as mean \pm standard error of three rats per group. Group A: neither induced nor treated; Group B: Formalin only (negative control); Group C: treated with W. cibaria II-1-59; Group D: treated with W. confusa JMC 1093; Group E: treated with P. pentosaceus DSM20336; Group F: treatment with diclofenac sodium (positive control). Values were found statistically significant at $\mathrm{P}<0.05$.

\section{Anti-inflammatory Cytokine (IL-10)}

Figure 3 depicts that the serum level of IL-10 in Group A at the first hour was $9.00 \pm 0.00 \mathrm{pg} / \mathrm{ml}$ and which remained constant throughout the period of the experiment. In untreated Group B rats, relatively low production of IL-10 was observed. An increased production of IL-10 was observed in LAB treated Groups reaching its maximum level at 1 hour. IL-10 level was highest in Group E rats $(72.20 \pm 0.00 \mathrm{pg} / \mathrm{ml})$ followed by Groups C and D at $59.9 \pm 0.00 \mathrm{pg} / \mathrm{ml}$ and
$57.3 \pm 0.00 \mathrm{pg} / \mathrm{ml}$, respectively while Group $\mathrm{F}$

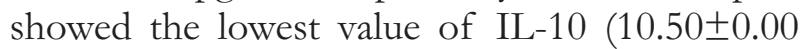
$\mathrm{pg} / \mathrm{ml}$ ) among treated rat groups. Group $\mathrm{F}$ also showed an increase in the production of IL-10 $(37.50 \pm 0.00 \mathrm{pg} / \mathrm{ml})$ at $8 \mathrm{hrs}$. Groups D and E rats showed serum IL-10 level between the ranges of $6.90 \pm 2.52 \mathrm{pg} / \mathrm{ml}-32.00 \pm 0.00 \mathrm{pg} / \mathrm{ml}$ after 24 hours till the end of $336 \mathrm{hrs}$. The values were tested for statistical significance at $\mathrm{p}<0.05$ and the effect of treatment means was compared. 


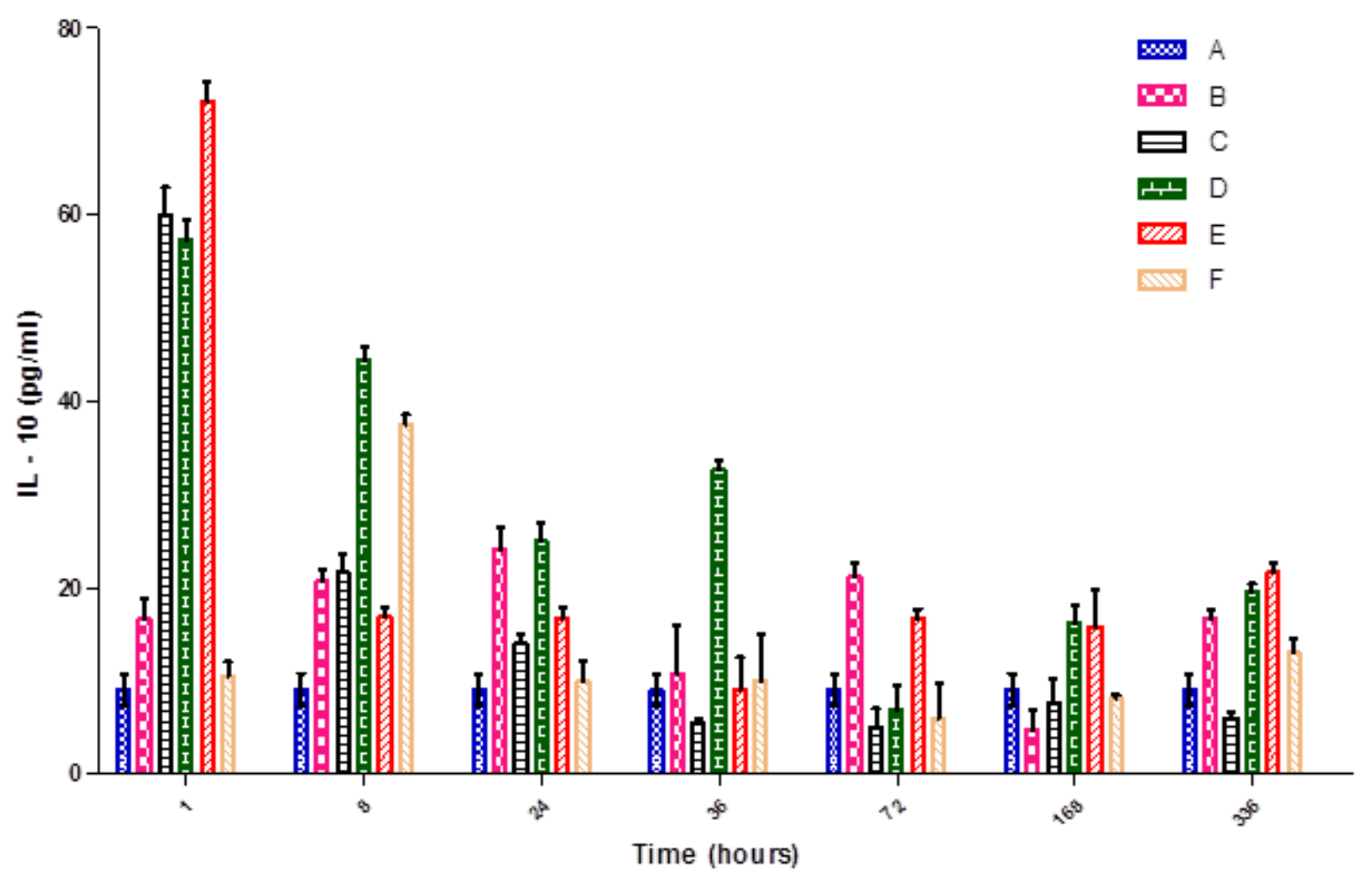

Figure 3: Production of IL-10 (pg/ml) att $=1,8,24,36,72,168$ and $336 \mathrm{hrs}$

$\mathrm{n}=3$ (significant at $\mathrm{P}<0.05$ ). Data are expressed as mean \pm standard error of three rats per group. Group A: neither induced nor treated; Group B: Formalin only (negative control); Group C: treated with W. cibaria II-1-59; Group D: treated with W. confusa JMC 1093; Group E: treated with P. pentosaceus DSM20336; Group F: treatment with diclofenac sodium (positive control). Values were found statistically significant at $\mathrm{P}<0.05$.

\section{E. Anti-inflammatory Cytokine (TGF- $\beta$ )}

Figure 4 reveals that the serum TGF- $\beta$ level of Group A rats at $\mathrm{t}=1$ hour was $62.90 \pm 5.00 \mathrm{pg} / \mathrm{ml}$ and remained constant till the end of $336 \mathrm{hrs}$. An increase in the production of TGF- $\beta$ was observed in Group B after the first hour and continued till the end of 72 hours. The highest value for TGF- $\beta$ was observed in Group $\mathrm{E}$ $(413.10 \pm 0.00 \mathrm{pg} / \mathrm{ml})$ at $\mathrm{t}=1 \mathrm{hr}$ and followed by Group F $(347.00 \pm 0.00 \mathrm{pg} / \mathrm{ml})$ at 8 hours while the lowest value was observed in Group C $(19.7 \pm 12.03 \mathrm{pg} / \mathrm{ml})$ at 72 hours. The values were tested for statistical significance at $\mathrm{p}<0.05$ and the effect of treatment means was compared. 


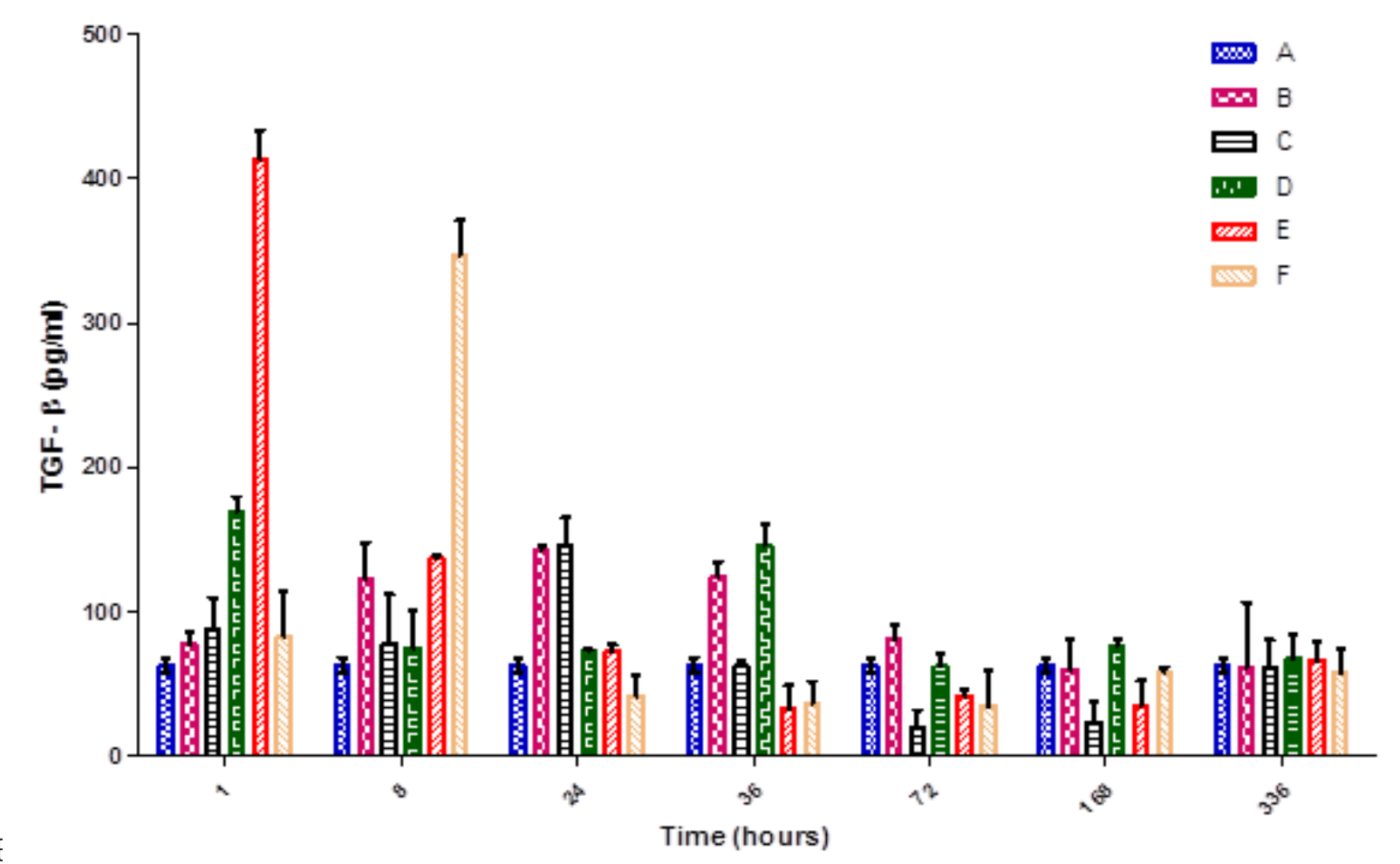

$\mathrm{n}=3$ (signiticant at $\mathrm{Y}<\boldsymbol{U}$.Uכ). $\mathrm{Vata}$ are expressed as mean \pm standard error of three rats per group. Group A: netther induced nor treated; Group B: Formalin only (negative control); Group C: treated with W. cibaria II-1-59; Group D: treated with W. confusa JMC 1093; Group E: treated with P. pentosaceus DSM20336; Group F: treatment with diclofenac sodium (positive control). Values were found statistically significant at $\mathrm{P}<0.05$.

\section{DISCUSSION}

Many lactic acid bacteria (LAB), such as Lactobacillus sp., Leuconostoc sp., Pediococcus sp. and Weissella sp. contribute to the fermentation of food products (Ouoba et al., 2010) including African locust beans (Parkia biglobosa). In this study, LAB isolated from African locust beans (Iru) were identified as $W$. cibaria II-1-59, $W$. confusa JMC 1093 and P. pentosaceus DSM20336 with accession no NR_036924.1, NR_040816.1 and NR_042058.1 respectively. Although Bacillus subtilis has been reported as the dominant bacterium involved in the fermentation, however, recent studies have also implicated lactic acid bacteria (LAB) in the alkaline fermentation of locust beans (Ouoba et al., 2010, Ajayi, 2014, Afolabi et al. 2016). This result appears similar to other studies that have successfully isolated and identified different types of lactic acid bacteria from fermented food products including African locust beans (Uaboi-Egbenni et al., 2009, Ouoba et al., 2010, Afolabi et al. 2016). Weissella sp., a relatively recent member of the lactic acid bacteria family, similar to the Leuconostoc was first identified in 1993 (Ahn et al., 2013; Fessard and Remize,
2017). In particular, $W$. cibaria has been isolated from fermented foods such as Korean kimchi, Greek salami, and Spanish sausages (Kwak et al., 2014). Weissella cibaria has been shown to possess anti-cancer, anti-inflammatory, antibacterial, antifungal, and immune boosting potentials (Kwak et al., 2014).

At the injection of a compound like formalin, release of inflammatory mediators such as histamine, serotonin, kinins, etc., starts the first phase leading to accumulation of fluids in the endothelial tissues. Within few hours, the second phase takes off with further release of prostaglandins and related substances. This is also characterized by leukocyte infiltration (especially primary response from neutrophils and monocytes) at the site of infection or damage following the activation of Pattern Recognition Receptors (PRRs) like Toll like receptors which is activated by cytokine production in a series of inflammatory cascade (Silva et al., 2010; Amdekar et al., 2012).

Oral administration of $W$. cibaria II-1-59, $W$. 
confusa JMC 1093 and P. pentosaceus DSM20336 significantly decrease the paw thickness of the rats (Group C, Group D and Group E). This showed that treatment with these LAB had very consistent anti-inflammatory effect and thus compared favorably with diclofenac sodium (standard NSAID drug). Prostaglandins play significant role in different phases of inflammatory response. Prostaglandins are the majority of molecules responsible for pain and inflammatory diseases. Also, cyclooxygenase (COX) which is involved in prostaglandins synthesis is the rate limiting enzyme. Prostaglandins have not only play pivotal role in inflammation, but these diverse molecules also regulate some critical physiological responses (Dubois et al., 1998). Various studies on immunomodulatory and anti-inflammatory activities of Weisella sp. and Pediococcus sp. have been reported supporting our findings (Kang et al., 2011, Ahn et al., 2013, Lv et al., 2014, Mizoguchi et al., 2017, Yu et al., 2019, Bian et al., 2020, Yin et al., 2020).

Pro-inflammatory biomarker (CRP) and antiinflammatory cytokines (IL-10 and TGF- $\beta$ ) were also estimated in this study. CRP is one of the many acute phase reactants that is elaborated in response to inflammation and/or tissue injury. CRP is produced in the hepatocytes of liver in response to IL-6 which is stimulated, in turn, by tumour necrosis factor- $a$ (TNF- $\alpha$ ) and IL-1 (Ahmed et al., 2012). Studies have shown that certain probiotic LAB have ability to downregulate pro-inflammatory cytokines (IL-6 and TNF- $\alpha$ ) while they upregulate the production of anti-inflammatory cytokines (IL-10 and TGF- $\beta$ ) (Amdekar et al., 2012). IL-10 is a cytokine with potent anti-inflammatory activity. IL-10 has been shown to be a potent macrophage deactivator, blocking the induced synthesis of $\mathrm{TNF}-\alpha$, IL-1, IL-6, IL-8, and GM-CSF by human monocytes (Trushin et al., 2003). Thus, alleviation of proinflammatory cytokines is important for improving inflammatory disorders. Also, previous studies have reported that IL-10 has inhibitory effect on COX-2 synthesis and, hence, the further action of prostaglandin which is a potent inflammatory mediator (Min et al., 2008). Treatment with $W$. cibaria II-1-59; $W$. confusa JMC 1093 and P. pentosaceus DSM20336 significantly decreased the secretion of pro-inflammatory biomarker (CRP) and increased the serum IL-10 and TGF- $\beta$ concentration of Group C, Group D and Group $\mathrm{E}$ rats. The present findings are consistent with the results of some other workers. For instance, Yu et al. (2019) reported that treatment with Weisella cibaria JW15 suppressed the expression of pro-inflammatory cytokines, IL-1, IL- 6 , and tumor necrosis factor- $\alpha$ in LPSinduced RAW 264.7 cells through regulation of NF- $x \mathrm{~B}$ activation. Additionally, $W$. cibaria inhibited production of IL-6 and IL-8 in Fusobacterium nucleatum-induced KB cells (Kang et al., 2011). The probable mechanism used by $W$. cibaria II-1-59, $W$. confusa JMC 1093 and P. pentosaceus DSM20336 could be prostaglandins inhibition due to high production of antiinflammatory cytokines (IL-10 and TGF- $\beta$ ) after treatment with these LAB. Prostaglandins plays significant role in inflammatory responses. This suggests that these lactic acid bacteria are promising anti-inflammatory agents in the treatment of inflammation.

\section{CONCLUSION}

The results of this present study showed that $W$. cibaria II-1-59, W. confusa JMC 1093 and P. pentosaceus DSM20336 possess anti-inflammatory potentials and suppresses the effect of inflammation in formalin-induced rat paw oedema, which further ascertain the health beneficial effect of the consumption of 'iru'.

\section{Competing interest}

Authors declare no competing interest.

\section{Acknowledgement}

Authors appreciate the efforts of the laboratory technologists of the Microbiology Department, Federal University of Technology, Akure for providing some necessary materials useful for the protocols employed in this study.

\section{Funding}

This study was funded independently by the authors in this study

\section{REFERENCES}

Afolabi, F.T., Abdulkadir, M. and Onilude, A. 2016. Isolation and screening of microorganisms associated with locust bean (iru) for the ability to ferment soya 
bean to produce soy iru. British Microbiology Research Journal, 13(6):1-10.

Ahmed, M.S, Jadhav, A. B., Hassan, A. and Meng, Q.H. 2012. Acute phase reactants as novel predictors of cardiovascular disease. International Scholarly Research Notices. Article ID 953461, 18 pages.

Ahn, S.B., Park, H.E., Lee, S.M., Kim, S.Y., Shon, M.Y. and Lee, W.K. 2013. Characteristics and immuno-modulatory effects of Weissella cibaria JW15 isolated from Kimchi, Korea traditional fermented food, for probiotic use. Journal of Biomedical Research. 14, 206-211.

Ajayi, A. O. 2014. Bacteriology and qualitative study of African locust bean (Parkia biglobosa). Open Journal of Sciences, 2: 73- 78.

Amdekar, S., Roy, P., Singh, V., Kumar, A., Singh, R., Sharma, P. 2012. Anti-inflammatory activity of Lactobacillus on carrageenaninduced paw edema in male Wistar rats. International Journal of Inflammation, 75:1-6.

Barcelos, I.P., Troxel, R.M. and Graves, J.S. 2019. Mitochondrial dysfunction and multiple sclerosis. Biology, 8(2): 37

Bian, X., Yang, L., Wu, W., Lv, L., and Jiang, X. (2020). Pediococcus pentasaceus L105 alleviates DSS-induced colitis by modulating immunological profiles, the gut microbiota and short-chain fatty acid levels in a mouse model. Microbial Biotechnoloy, 13(5): 1228-1244.

Bin Masalam, M.S., Bahieldin, A., Alharbi, M.G., Al-Masaudi, S., Al-Jaouni, S.K., Harakeh, S.M., Al- Hindi, R.R., 2018. Isolation, molecular characterization and probiotic potential of lactic acid bacteria in Saudi raw and fermented milk. Evidence-Based Complementary and Alternative Medicine, pp.1-12.

Dubois, R.N., Abramson, S.B., Crofford, L., Gupta, R.A., Simon, L. S. and Van de Putte, L.B.A., et al. 1998. Cyclooxygenase in biology and disease. FASEB Journal, 12:1063-79.

Fessard, A. and Remize, F. 2017. Why are Weissella spp. not used as commercial starter cultures for food fermentation? Fermentation, 3(38): 1-31.

Gulati, K., Guhathakurta, S., Joshi, J. and Ray, A. 2016. Cytokines and their roles in health and diseases: A Brief Overview. MOJ Immunology, 4(2):1-9.

Jain, P., Pendey, R. and Shukla, S.S. 2015. Inflammation: natural resources and its application. Springer Briefs in Immunology. Pp 5-24 ISBN 978-81-322-2162-3.

John, N. A. and Shobana, G. 2012. Antiinflammatory activity of Talinum fruticosum L. on formalin induced paw edema in albino rats. Journal of Applied Pharmacentical Science, 02(01): 123-127.

Kang, M.S., Lim, H.S., Kim, S.M., Lee, H.C. and Oh, J.S. 2011. Effect of Weissella cibaria on Fusobacterium nucleatum-induced interleukin-6 and interleukin-8 production in $\mathrm{KB}$ cells. Journal of Bacteriology and Virology, 41: 9-18.

Kwak, S.H., Cho, Y.M., Noh, G.M. and Om, A.S. 2014. Cancer preventive potential of kimchi lactic acid bacteria (Weissella cibaria, Lactobacillus plantarum). Journal of Cancer Prevention, 19(4): 253-258.

Lv, L.X., Hu, X.J., Qian, G.R., Zhang, H., Lu, H.F., Zheng, B., Jiang, L. and Li, L.J. 2014. Administration of Lactobacillus salivarius L101 or Pediococcus pentasaceus L105 improves acute liver injury induced by $\mathrm{D}$ -galactosamine in rats. Applied Microbiology and Biotechnology. 98(12): 5619-5632.

Michels da Silva, D., Langer, H. and Graf, T. 2019. Inflammatory and molecular pathways in heart failure-ischemia, hfpef and transthyretin cardiac amyloidosis. International Journal of Molecular Science, $20(9): 2322$.

Min, L.J., Hwang, K., Jun, W.J., Park, C. and Lee, M. 2008. Anti-inflammatory effect of lactic acid bacteria: inhibition of cyclooxygenase-2 by suppressing nuclear factor- $x$ B in RAW264.7 Macrophage cells. Journal of Microbiology and Biotechnology, 18(10):1683-8.

Mizogushi, T., Kasahara, K., Yamashita, T. and Sasaki, N. 2017. Oral administration of the lactic acid bacteria-Pediococcus acidilactici attenuates atherosclerosis in mice by inducing tolerogenic decdritic cells. Heart and vessels, 32(6):768-776.

Monastero, R.N. and Pentyala, S. 2017. Cytokines as biomarkers and their respective clinical cut off levels, International Journal of 
Inflammation. Article ID 4309485, Pp 1-11.

Ouoba, L.I., Nyanga-Koumou, C.A., Parkouda, C., Sawadogo, H., Kobawila, S.C., Keleke, S., Diawara, B., Louembe, D., and J.P. Sutherland. 2010. Genotypic diversity of lactic acid bacteria isolated from African traditional alkaline-fermented foods. Journal of Applied Microbiology, 108: 2019-2029.

Pessione, E. 2012. Lactic acid bacteria contribution to gut microbiota complexity: Lights and shadows. Frontiers of Cell Infection and Microbiology, 2(86): 1-15.

Silva, F.R.F., Dore, C.M.P.G., Marques, C.T., Nascimento, M.S., Benevides, N.M.B., Rocha, H.A.O., Chavante, S.F. and Leite, E.L. 2010. Anticoagulant activity, paw edema and pleurisy induced carrageenan: action of major types of commercial carrageenan. Carbobydrate Polymers, 79: 26-33.

Trushin, S. A., Pennington, K. N. and Carmona, E. M. 2003. "Protein kinase $\mathrm{C} a(\mathrm{PKC} a)$ acts upstream of $\mathrm{PKC} \theta$ to activate $\mathrm{I} \gamma \mathrm{B}$ kinase and NF-xB in T lymphocytes," Molecular and Cellular Biology, 23(19): 7068-7081

Uaboi-Egbenni, P. O., Okolie, P. N., Sobande, A. O., Alao, O., Teniola, O. and Bessong P. O. 2009. Identification of subdominant lactic acid bacteria in dawadawa (a soup condiment) and their evolution during laboratory-scale fermentation of Parkia biglobosa (African locust beans). African Journal of Biotechnology, 8(25): 7241-7248.

Valentini, L., Pinto, A., Bourdel-Marchasson, I., Ostan, R., Brigidi, P. and Turroni, S. 2015. Impact of personalized diet and probiotic supplementation on inflammation, nutritional parameters and intestinal microbiota - The "RISTOMED project": randomized controlled trial in healthy older people. Journal of Clinical Nutrition, 34: 593-602.

Yin, H., Ye, P., Lei, Q., Chag, Y., Yu, H., Du, J., Pan, H. and Cao, Z. 2020. In vitro probiotic properties of Pediococcus pentasaceus L1 and its effect on enterotoxigenic E. coliinduced inflammatory response in porcine intestinal epithelial cells. Microbial pathogenesis, 144:104163.

Yu, H., Lee, N., Choi, A. Choe, J., Bae, C.H. and Paik, H. 2019. Anti-Inflammatory potential of probiotic strain Weissella cibaria jw15 isolated from kimchi through regulation of $\mathrm{nf}-x \mathrm{~b}$ and mapks pathways in lps-induced raw 264.7 Cells. Journal of Microbiology and Biotechnology, 29(7): 1022-1032 